\title{
OBITUARIES
}

For the full versions of articles in this section see bmj.com

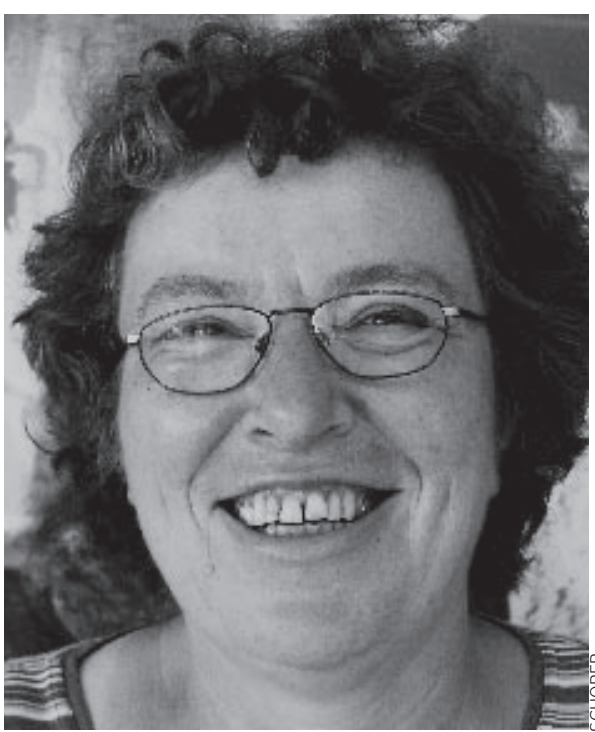

\section{Riek Stienstra}

\section{Put gay and lesbian health on the map in wake of the HIV/AIDS pandemic}

Riek Stienstra was perhaps the right woman in the right place at the right time. Faced with the first casualties of the HIV/AIDS pandemic in the 1980s, Amsterdam's gay community suffered shock, panic, fury, and despair. But to this trauma she brought compassion, pragmatism, and leadership, launching the Netherlands first buddy projects, and ensuring that the gay community was heard in the sometimes desperate struggle against the pandemic.

Stienstra was born in rural Friesland in the north of the Netherlands in 1942. She trained as a social worker and joined the Humanitas Foundation in Amersfoort-a humanitarian organisation providing social services, partly through volunteers. In 1974 she applied to what was then known as the SAD-Schorer Foundation, a small scale "consultation bureau" for homosexuality. It reflected what were still, in the 1970s, patronising attitudes. In particular it was reluctant to employ gay men and lesbians for fear that they would be too emotionally involved.

That changed with Stienstra, who proudly declared that being homosexual herself meant that she felt a certain affinity with the problems the foundation faced. In a quarter of a century as director she put gay and lesbian health and welfare on the map, turning Schorer into one of the largest health promotion bodies in this field in Europe.

However, her outspoken nature and unbridled energy were to be severely tested with the arrival of the HIV/AIDS pandemic. The first five cases of AIDS were diagnosed in the Netherlands in 1982.

Former colleague and friend Peter Van Rooijen, now director of International Civil Society Support, working on HIV/ AIDS prevention, joined Schorer in 1985. He remembers: "It was tough, our clients were dying. We were actually in shock. She remained strong and kept the organisation focused on a longer term vision, even if sometimes she could have had more of an eye for the personal needs of her employees." The burnout rate was high.

But Stienstra brought the voice and the concerns of the gay community to the debate. She too earned respect for Schorer, which until then was not seen as part of the mainstream healthcare environment.

She became the public face of Schorer and, especially in the early years, ensured that HIV and AIDS were openly discussed in public. She later said of the challenge: "every disadvantage has an advantage," and AIDS meant that Schorer, out of necessity, became a rich source of expertise, information, and networking.

She addressed fear with pragmatism, in particular launching the Netherlands first two buddy projects in 1985, with Schorer hiring experts from the United States. These projects addressed the needs of the gay community in the mid-1980s, not just for prevention but for psychosocial care. Many people with AIDS were young gay men living alone, often estranged from their families, and home care staff were still frightened to provide services.

Buddies offered practical peer support and assurance that someone would be there to help in the simplest of tasks, such as climbing stairs. Later Stienstra was to comment how moved she was that "so many men mothered AIDS patients to the bitter end."

The buddy projects reached a peak of up to 250 volunteers before the introduction of combination treatments in 1996. The Dutch model was later re-exported to countries in the developing world, particularly South America.

Stienstra also had a hard headed approach to finances that colleagues called visionary. She had the courage and foresight to risk hiring teams for the buddy projects while still in the middle of a protracted struggle with the government over how to fund them. Later she found funds to recompense buddy volunteers, not because individuals necessarily deserved it but because she wanted society to formally acknowledge their worth.

She also brought awareness of the political dimension. She fought the government again and again, refusing to accept rejections for funding; knowing that this would at least raise its profile through parliamentary debates.

Famously she is said to have replied to Queen Beatrix, when struggling with steep stairs during a fact finding visit to their cramped former offices on the Nieuwendijk in the centre of Amsterdam in 1989, "Your majesty, we can't all live in a palace." The ministry of health called within weeks to offer Schorer new premises which it had been trying to find for years.

Clearly royalty admired her humour for on retirement in 2002 she became a companion of the order of Orange-Nassau for her public work.

Together with her work for Schorer, Stienstra was active in campaigns for gay and lesbian emancipation, especially as treasurer of a foundation for homosexual studies which established academic chairs at both Amsterdam and Maastricht Universities.

Today's director of the Netherlands AIDS Funds and STI AIDS Netherlands, Ton Coenen, wrote after her death that as soon as HIV/AIDS arrived in the Netherlands "she rolled up her sleeves . . . and together with many others built everything from scratch, because it was new, enormously threatening, and there was no one who knew what must be done. Without Riek everything would have taken longer."

Riek Stienstra, director of Schorer, Amsterdam's gay and lesbian health foundation, 1974-2002

(b 1942), died from bowel cancer on 20 November 2007.

Tony Sheldon

OBITUARIES continue on p 103 


\section{Alan Marcus Barker}

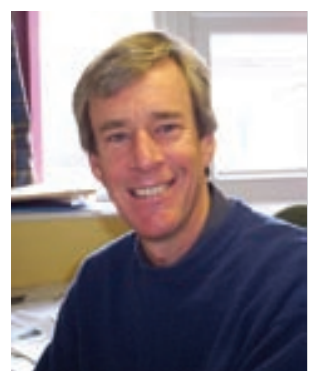

General practitioner and trainer and mentor in general practice Newhaven, East Sussex (b 1953; q Guy's Hospital, London, 1980; BA Hons Physics, DRCOG, MRCGP), d 24 August 2007. Alan was born in India and came to England when he was 6. He spoke Hindi before English. Before studying medicine, he read physics at $0 x f o r d$ University. After qualifying he worked in the Brighton area and trained as a general practitioner in the Brighton Vocational Training Scheme. On many occasions he participated in charity cycle rides as medical officer, often in developing countries. He leaves a wife, Wendy, and two children.

Roger Figgins for Quayside Medical Practice

\section{Noel Frank Collett Gowing}

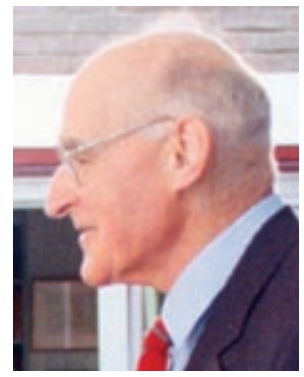

Former professor of tumour pathology Royal Marsden Hospital, London (b

1917; q St George's Hospital, London, 1941; MD, FRCPath), died from

carcinomatosis on 17 September 2007. After house jobs at St George's Hospital, Noel Frank Collett Gowing served in Europe as a captain in the Royal Army Medical Corps. Returning to St George's in 1945, he trained in histopathology, becoming senior lecturer there. He moved to the Royal Marsden Hospital as consultant histopathologist in 1957, and was later awarded a personal chair. He retired in 1982 but continued to work as a coroner's pathologist, as well as teaching histopathology to students at Guy's, until he reached 80. A founder fellow and subsequently registrar of the Royal College of Pathologists, he was also president of the Association of Clinical Pathologists. He leaves a wife, Rela; a daughter; and two grandchildren. Stephen Kane

\section{William Kerr Henderson}

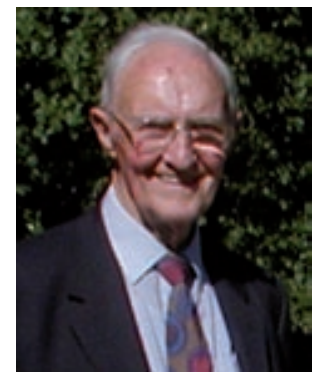

Former general practitioner Hawick, Scottish Borders, and medical administrator Scottish Home and Health Department (b 1912; q Edinburgh 1935; MD, FRCP(Ed), FR(GP), died on 23 October 2007 from complications after a fall.

After house jobs and a short spell in clinical research, William Kerr Henderson ("Bill”) was a general practitioner in Hawick for 10 years, also gaining his MD and MRCP. In 1948 he became senior medical officer to the Scottish Home and Health Department in Glasgow before becoming principal medical officer in Edinburgh. He facilitated the changes introduced in general practice in the 1960s and'70s, including structured training and recognition of general practice as a specialty. He was an elder in the Kirk for 61 years. Predeceased by a daughter and by his wife, Thora, he leaves two sons and seven grandchildren. Andrew K Henderson

\section{Anthony James Sear}

Former oral and maxillofacial consultant Mid and South Worcestershire Hospitals (b 1930; q Birmingham 1964; BDS, FDS), d 20 April 2007.

Anthony James Sear (“Tony”) introduced operations for correction of facial deformity pioneered in Europe after attending the University Hospital in Zurich. With his anaesthetist colleague he developed a simple, reliable moulded plastic laryngoscope. He did work exchanges with consultant colleagues in Napier, New Zealand, and Kampala, in postAmin Uganda. He had previously completed his national service in West Africa. Despite his one in two on-call commitment, he constructed a single seat light aircraft in his garage, which he flew until a crash landing with engine failure, escaping with only a torn shirt. He leaves a wife, Catherine; three children; and two grandchildren.

C M Sear

\section{Ann Elizabeth Snedden}

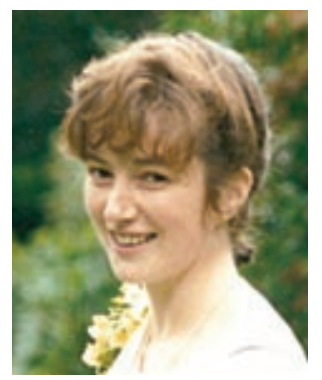

Consultant child and family psychiatrist Glasgow (b 1960; q Glasgow 1983; DRCOG, MRCPsych), died from a brain tumour on 1 September 2007. After qualifying as a general practitioner in Perth, Ann Elizabeth Snedden specialised in psychiatry, training at Woodilee and Gartnavel Royal Hospitals in Glasgow.

She completed her training in psychoanalytical child psychotherapy at the Scottish Institute of Human Relations. In her work as consultant for the child psychiatry team at Possilpark Health Centre she was widely respected for improving the emotional health of heryoung patients in a highly deprived area of Glasgow. She leaves a husband, Keith Turner, and a daughter.

Ama Addo, Sarah Beesley, Alison Cohen, Kate Slaven

\section{Robert Alexander Harrison Surtees}

Head Neurosciences Unit, UCL Institute of Child Health (b 1955; q Oxford 1980; PhD, FRCP, FRCPCH), d 18 August 2007. An open exhibitioner at St Edmund Hall, Oxford, RobertAlexander Harrison Surtees came to the UCL Institute of Child Health and

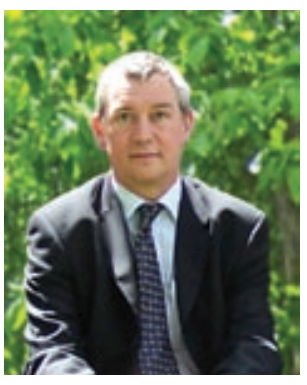

Great Ormond Street Hospital in 1986 as Wellcome Trust lecturer. He rapidly became professor of paediatric neurology and honorary consultant and ultimately head of the Neurosciences Unit. His PhD was on s-adenosylmethionine deficiency and demyelination, and he developed analytical biochemical methods to measure metabolites in body fluids, particularly cerebrospinal fluid, to investigate demyelination in inborn errors of vitamin B12 and folate metabolism and acute leukaemia, and the role of excitotoxicity in cerebral malaria and disordered amine neurotransmission in early onset movement disorders. He leaves a wife, Diane, and two sons.

Brian Neville

\section{Michael Kingsley Williams}

Former general practitioner Ashtead, Surrey (b 1929; q Oxford/St Mary's Hospital, London, 1958; DObstRCOG, DIH, MRCGP), died from heart failure on 21 August 2007.

Michael Kingsley Williams (“Mike") switched from engineering to medicine while at Oxford. He was medical officer at Chloride Batteries, Manchester, before obtaining his DM on lead toxicity in 1968 from the London School of Hygiene and Tropical Medicine. He was asked to apply for the chair in occupational medicine at the London school but happened on the Ashtead surgery where he was subsequently general practitioner and GP trainer until retirement in 1996. He continued his interest in occupational health, visiting Exide Batteries, Dagenham, on alternate Fridays. He also cofounded the Bowden Symphony Orchestra, but mostly played in the Surrey Philharmonic Orchestra. Predeceased by his wife, Judy, in 1997, he leaves four children. Frances Williams 